\title{
Effect of Saccharomyces boulardii and Lactobacillus acidophilus fermentation on little millet (Panicum sumatrense)
}

\author{
Pampangouda $^{1 *}$, K. B. Munishamanna ${ }^{2}$ and H. Gurumurthy ${ }^{1}$ \\ ${ }^{1}$ Department of Agricultural Microbiology, University of Agricultural Sciences, Bangalore-560065, INDIA \\ ${ }^{2}$ Food microbiologist PHT scheme, University of Agricultural Sciences, Bangalore-560065, INDIA \\ *Corresponding Author. E-mail:pampannagoudap@gmail.com \\ Received: December 3, 2014; Revised received: March 5, 2015; Accepted: April 14, 2015
}

\begin{abstract}
The fermentation of little millet (Panicum sumatrense) carried out by probiotic yeast (Saccharomyces boulardii) and lactic acid bacteria (Lactobacillus acidophilus). The germinated little millets grains were fermented for 5 days grains were dried and grounded in a grinder and sieved. The sieved flours were analyzed for proximate composition, minerals and phytic acid content. The results showed that the little millet fermented by combined inoculation of Saccharomyces boulardii and $L$. acidophilus significantly enhanced protein content $(10.95 \%)$ and decreases the fat $(2.61 \%)$ and carbohydrate (82.01\%) and single inoculation with $L$. acidophilus decreased the fibre (1.05\%) and ash (2.30\%). Single inoculation of $L$. acidophilus enhanced the minerals content $\mathrm{Ca}(41.44 \mathrm{mg}), \mathrm{Mg}$ (141.08 mg), phosphorus (238.43mg), Fe $(7.98 \mathrm{mg})$ and $\mathrm{Zn}(4.69 \mathrm{mg})$ and over dual inoculation and control treatments. Similarly, Single inoculation of Lactobacillus acidophilus showed significant reduction in phytic acid (114.76 mg) content over dual inoculation $(126.49 \mathrm{mg})$ and control $(188.95 \mathrm{mg})$ treatments. The results indicated that fermentation of little millet by L. acidophilus enhanced mineral contents and reduction in phytic acid content.
\end{abstract}

Keywords: Lactobacillus acidophilus, Little millet, Probiotic, Saccharomyces boulardii

\section{INTRODUCTION}

India attained self-sufficiency in food production to meet the required quantity. However, malnutrition is one of the major nutritional constraints mainly due to protein deficiency in the country and in other developing countries like India. Little millet (Panicum sumatrense) is one of the minor millets and called by many names such as Kutki in Hindi, Samai in Tamil, Sama in Telugu, Same/savi in Kannada and Chama in Malayalam. Little millet cultivation is seen in India to a limited extent up to altitudes of $2100 \mathrm{~m}$, but is of little importance elsewhere. This millet is used in Tamil Nadu, Karnataka, Andhra Pradesh, Maharashtra, Jharkhand, Madhya Pradesh and Orissa. It is Gujarat and grown quite extensively in many parts of the country. The crop is strongly associated with tribal agriculture and grown as an important catch crop in view of its fast growing and resistance to adverse agroclimatic conditions. The stover is a good fodder for cattle (Sharma, 2008)

Although little millets are superior to other cereals with many nutritional benefits, their utilisation is limited mainly to poor section of population or to cattle and poultry feed, or finds place as fasting food, reason being low palatability coarseness of grain, lack of time to process the grains and slow the digestibility of protein and carbohydrates. As millets are coarse grains having higher amounts of polyphenols the colour and flavour becomes unacceptable to new consumer. Further, the non-availability of processed millet in ready to use form is another hurdle in its utilization. The value addition to small millets through processing technology is receiving good attention in terms of the development of several types of value added products (Ranganna, et al., 2012). Many kinds of traditional foods/ snacks are being made from small millet grains in the form of staple diet for many rural and urban households. Fermentation is an efficient process in the development of new products with modified physical and chemical properties, improved sensory quality of flavor, nutrition besides therapeutic value. The present study was undertaken to study the effect of Saccharomyces boulardii and Lactobacillus acidophilus fermentation on little millet (Panicum sumatrense).

\section{MATERIALS AND METHODS}

Collection of little millets for experiments: The experiments related to Microbial fermentation of little millets for the nutritional improvement. Were conducted in the Department of Agricultural Microbiology and Post -harvest technology scheme, University of Agricultural Sciences, Gandhi Krushi Vignan Kendra, Bangalore.

Microbial fermentation of little millets: The experiment was conducted to study the influence of probiotic yeast (S. boulardii) and lactic acid bacterial (.L. acidophilus) fermentation of little millet through solid state fermentation.

Preparation of little millets substrates for solid state fermentation: Little millet was cleaned thoroughly, 
the grains were soaked in distilled water for $24 \mathrm{hrs}$. at room temperature. A seed to water ratio of 1:5 (w/v) was used. The imbibed water was decanted. The imbibed and soaked seeds were kept for germination in a tray using sterile muslin cloth for $48 \mathrm{hrs}$. at room temperature with frequent spraying of water. After $48 \mathrm{hrs}$. the sprouts /germinated grains were rinsed in distilled hot water at $60^{\circ} \mathrm{C}$ with 0.1 per cent potassium meta-bisulphite (KMS solution). After rinsing with KMS solution, the germinated little millet grain samples were transferred into polythene bags of 400 gauges for solid state fermentation process.

Preparation of probiotic yeast starter culture: Purified and authenticated loop full of inoculum of probiotic yeast $S$. boulardiiwas inoculated to conical flask containing Sabourauds Hi-media broth. The inoculated flasks were kept for $48 \mathrm{hrs}$. Incubation at $28^{\circ} \mathrm{C}$. The broth culture of probiotic yeast was inoculated at 5 per cent containing $10^{7} \mathrm{cfu} / \mathrm{ml}$ to $500 \mathrm{~g}$ of germinated millet grains contained in polythene bags under solid state fermentation process.

Preparation of probiotic LAB starter culture: Loop full inoculum of purified and authenticated probiotic lactic acid bacteria L. acidophilus were transferred to conical flasks containing $100 \mathrm{ml}$ of MRS broth. Inoculated flasks were incubated for $48 \mathrm{hrs}$. at $37^{\circ} \mathrm{C}$. These broth cultures of LAB were inoculated at 5 per cent containing $10^{7} \mathrm{cfu} / \mathrm{ml}$ to $500 \mathrm{~g}$ of millets contained in polythene bags under solid state fermentation.

\section{Experimental treatment details in four replications were} as follows:

$\mathrm{T}_{1}$ : Little millet germinated grains (Control)

$\mathrm{T}_{2}$ : Little millet germinated grains $+S$. boulardii

$\mathrm{T}_{3}$ : Little millet germinated grains + L. acidophilus

$\mathrm{T}_{4}$ : Little millet germinated grains $+S$. boulardii $+L$. acidophilus.

Fermentation was carried out for five days

Tray drying

After completion of 5 days of fermentation, the samples were subjected to drying in tray drier at $50^{\circ} \mathrm{C}$ for 48 hrs. Samples were spread uniformly in the tray drier for effective drying.

De-husking of fermented germinated grains of little millet: The fermented little millets were processed (de-husked) using a Domestic Burr Mill (make: Ashirwad Co., Ahmedabad) to get de-husked grains of foxtail and little millet for grinding.

Grinding: Fermented dried germinated little millet was grinded in mixer/ grinder to get flour and sieved in BS 18 mesh sieve. The sieved flour of different millets were packed in polyethylene bags of 400 gauges and stored under room temperature.

Biochemical and microbiological analysis: The fermented flours of little millets were subjected to proximate analysis of different nutrients such as moisture, protein , fat, fibre, ash and carbohydrate (AOAC, 1980) content at initial ( 0 day) and after 3 months storage period and mineral contents of calcium, phosphorous, zinc, magnesium, iron and antinutritional factor phytic acid content. Phytic acid was determined by the method of Haug and Lantzsch (1983). The fermented millets samples were subjected to microbiological analysis of yeast and lactic acid bacterial counts by employing standard dilution plate count method (Hoben and Somasegaran, 1982).

Statistical analysis: The treatments difference was separated at 5 per cent significance level using Duncan's multiple range test.

\section{RESULTS AND DISCUSSION}

In the present study, the moisture percentage of germinated little millet flour was the highest $(7.34 \%)$ while that fermentation by yeast and LAB strains showed lower moisture percentage $(6.80$ to $6.95 \%)$. However, the lowest moisture percentage $(6.80 \%)$ was observed in the fermented by combined inoculation of $S$. boulardii and $L$. acidophilus was made followed by single inoculation of L. acidophilus $(6.84 \%)$ and $S$. boulardii inoculation $(6.95 \%)$ (Table 1$)$. These values were within the range reported by other investigators (Reihaneh and Jamuna, 2007; Amagloh et al., 2012). However, investigations have shown that low moisture content of food samples is desirable phenomenon since microbial activity is reduced (Oyenuga, 1968). Similar results were earlier reported by Ijarotimi (2012) in wheat flour. The slight change in moisture content during storage for 90 days and quality of fermented flour will not change. Similar findings were reported by Chandru, et al., (2007) in finger millet flour where slight increase in moisture content till 6 month of storage period.

The protein content of the microbialy processed little millet flour samples varied between 9.86 to 10.95 per cent, protein content in the germinated flour was 9.86 per cent. The protein content of fermented flour by the influence of $S$. boulardii and L. acidophilus has significantly enhanced the protein content compared to germinated flour, it is an indicative of the carbohydrates in the substrate which utilized by the strains of $S$. boulardii and $L$. acidophilus. However, the combined inoculation of $S$. boulardii and L. acidophilus has significantly increased the crude protein content of little millet $(10.95 \%)$ (Table 1$)$. This observation agreed with other scientific findings that fermentation improved the nutritional quality of the food products, particularly in terms of protein content (Fasasi,2009), This finding could be attributed to the fact that during fermentation process the microorganisms in food utilized the carbohydrate content in food sample to synthesis amino acid needed for their growth and development (Obizoba, 1988). The slight change in protein content during storage for 90 days is non-significant between the treatments, hence the changes did not influenced on quality and shelf-life of flour up to 3 months in all the samples. Similar results were reported by Chandru, et al., (2010) where protein content was slightly decreased in finger millet flour up to 6 month storage.

The lowest crude fat $(2.61 \%)$ was observed in the little 
Table 1. Influence of $S$. boulardii and L. acidophilus fermentation on proximate composition of the little millet flour at initial and after 3 months storage (on dry weight basis).

\begin{tabular}{|c|c|c|c|c|c|c|c|c|c|c|c|c|}
\hline \multirow{3}{*}{ Treatments } & \multicolumn{12}{|c|}{ Storage (months) } \\
\hline & \multicolumn{2}{|c|}{ Moisture (\%) } & \multicolumn{2}{|c|}{ Protein $(\%)$} & \multicolumn{2}{|c|}{ Fat $(\%)$} & \multicolumn{2}{|c|}{ Ash (\%) } & \multicolumn{2}{|c|}{ Fibre (\%) } & \multicolumn{2}{|c|}{$\begin{array}{c}\text { Carbohydrates } \\
(\%)\end{array}$} \\
\hline & $\mathbf{0}$ & 3 & $\mathbf{0}$ & 3 & $\mathbf{0}$ & 3 & $\mathbf{0}$ & 3 & $\mathbf{0}$ & 3 & 0 & 3 \\
\hline $\mathrm{T}_{1}$ & $7.34^{\mathrm{a}}$ & $7.58^{\mathrm{a}}$ & $9.86^{\mathrm{d}}$ & $9.66^{\mathrm{c}}$ & $3.26^{\mathrm{a}}$ & $3.21^{\mathrm{a}}$ & $2.27^{\mathrm{c}}$ & $2.21^{\mathrm{b}}$ & $1.15^{\mathrm{a}}$ & $1.13^{\mathrm{a}}$ & $84.54^{\mathrm{a}}$ & $83.76^{\mathrm{a}}$ \\
\hline $\mathrm{T}_{2}$ & $6.95^{\mathrm{b}}$ & $6.99^{b}$ & $10.74^{\mathrm{b}}$ & $9.82^{b}$ & $2.92^{\mathrm{c}}$ & $2.74^{\mathrm{b}}$ & $2.34^{\mathrm{a}}$ & $2.27^{\mathrm{a}}$ & $1.09^{\mathrm{c}}$ & $1.09^{\mathrm{ba}}$ & $82.94^{\mathrm{c}}$ & $82.11^{\mathrm{c}}$ \\
\hline $\mathrm{T}_{3}$ & $6.84^{\mathrm{c}}$ & $6.91^{\mathrm{c}}$ & $10.40^{\mathrm{c}}$ & $9.75^{\mathrm{c}}$ & $3.09^{\mathrm{b}}$ & $2.98^{\mathrm{b}}$ & $2.30^{\mathrm{b}}$ & $2.23^{\mathrm{b}}$ & $1.05^{\mathrm{d}}$ & $1.01^{\mathrm{b}}$ & $83.18^{\mathrm{b}}$ & $82.06^{\mathrm{d}}$ \\
\hline $\mathrm{T}_{4}$ & $6.80^{\mathrm{c}}$ & $6.89^{\mathrm{c}}$ & $10.95^{\mathrm{a}}$ & $10.29^{\mathrm{a}}$ & $2.61^{\mathrm{d}}$ & $2.44^{\mathrm{c}}$ & $2.34^{\mathrm{a}}$ & $2.21^{\mathrm{b}}$ & $1.11^{\mathrm{b}}$ & $1.11^{\text {ba }}$ & $82.01^{\mathrm{d}}$ & $82.48^{\mathrm{b}}$ \\
\hline
\end{tabular}

Table 2. Influence of S. boulardii and L. acidophilus fermentation on minerals of little millet flour.

\begin{tabular}{ccccccc}
\hline Treatments & $\begin{array}{c}\text { Calcium } \\
(\mathbf{m g} / \mathbf{1 0 0 g})\end{array}$ & $\begin{array}{c}\text { Magnesium } \\
(\mathbf{m g} / \mathbf{1 0 0 g})\end{array}$ & $\begin{array}{c}\text { Phosphorus } \\
(\mathbf{m g} / \mathbf{1 0 0 g})\end{array}$ & $\begin{array}{c}\text { Iron } \\
(\mathbf{m g} / \mathbf{1 0 0 g})\end{array}$ & $\begin{array}{c}\text { Zinc } \\
(\mathbf{m g} / \mathbf{1 0 0 g})\end{array}$ & $\begin{array}{c}\text { Phytic acid } \\
(\mathbf{m g} / \mathbf{1 0 0 g})\end{array}$ \\
\hline T1 & $39.20^{\mathrm{b}}$ & $137.62^{\mathrm{b}}$ & $221.48^{\mathrm{d}}$ & $6.67^{\mathrm{bc}}$ & $3.87^{\mathrm{b}}$ & $188.95^{\mathrm{a}}$ \\
T2 & $40.32^{\mathrm{ab}}$ & $137.73^{\mathrm{b}}$ & $226.40^{\mathrm{c}}$ & $6.97^{\mathrm{c}}$ & $3.95^{\mathrm{b}}$ & $167.56^{\mathrm{b}}$ \\
T3 & $41.44^{\mathrm{a}}$ & $141.08^{\mathrm{a}}$ & $234.43^{\mathrm{a}}$ & $7.98^{\mathrm{a}}$ & $4.69^{\mathrm{a}}$ & $114.76^{\mathrm{d}}$ \\
T4 & $40.98^{\mathrm{a}}$ & $138.58^{\mathrm{b}}$ & $229.76^{\mathrm{b}}$ & $7.22^{\mathrm{b}}$ & $4.01^{\mathrm{b}}$ & $126.49^{\mathrm{c}}$ \\
\hline
\end{tabular}

Table 3. S. boulardii and L. acidophilus population in fermented little millet flour.

\begin{tabular}{|c|c|c|c|c|c|c|}
\hline \multirow{3}{*}{ Treatments } & \multicolumn{6}{|c|}{ Storage (days) } \\
\hline & \multicolumn{3}{|c|}{$\begin{array}{c}\text { S. boulardii } \\
\left(\mathrm{cfu} \times 10^{6} / \mathrm{g} \text { of flour }\right)\end{array}$} & \multicolumn{3}{|c|}{$\begin{array}{c}\text { L. acidophilus } \\
\left(\mathrm{cfu} \times 10^{6} / \mathrm{g} \text { of flour }\right)\end{array}$} \\
\hline & $\mathbf{0}$ & 45 & 90 & $\mathbf{0}$ & 45 & 90 \\
\hline $\mathrm{T} 1$ & ND & ND & ND & ND & ND & ND \\
\hline $\mathrm{T} 2$ & 2.46 & 1.54 & 0.41 & ND & ND & ND \\
\hline $\mathrm{T} 3$ & ND & ND & ND & 3.21 & 1.69 & 0.85 \\
\hline $\mathrm{T} 4$ & 0.93 & 0.61 & 0.31 & 1.45 & 0.83 & 0.47 \\
\hline
\end{tabular}

Little millet was germinated and fermentation was up to 5 days and processed into flours. ND- Not determined. DAS: Days after storage

millet fermented by combined inoculation of $S$. boulardii and L. acidophilus followed by $S$. boulardii fermentation $(2.92 \%)$, the germinated little millet (uninoclated) showed higher crude fat $(3.26 \%)$ (Table1). The results support the work of Inyang and Zakari (2008) who reported that fat levels in fermented pearl millet flour decreases. The slight change in protein content during storage for 90 days is non-significant between the treatments. Hence the changes did not influenced on quality and shelf-life of flour up to 3 months in all the samples.

The highest ash content $(2.34 \%)$ was observed in the little millet fermented by single inoculation of S.boulardii and combined inoculation S. boulardii and $L$. acidophilus followed by single inoculation of $L$. acidophilus $(2.30 \%)$ and lowest ash content observed in control $(2.27 \%)$ (Table 1$)$.

The crude fibre of fermented little millet showed slight reduction compared to control (1.15\%). However, crude fibre content was low in the L. acidophilus fermentation $(1.05 \%)$ (Table 1$)$. These results are in similar to those reported earlier in sorghum-cowpea blends fermented by $L$. plantarum and $S$. cervisiae
(Wakil and Kazeem, 2012).

The carbohydrates of fermented little millet showed decrease during fermentation when combined inoculation of S. boulardii and L. acidophilus strains (82.01\%) compared to control $(84.54 \%)$ (Table1). The carbohydrate content of fermented samples was lower than the un inoculated control samples. This observation could be due to the utilization of carbohydrates by $S$. boulardii and $L$. acidophilus during fermentation activity. These results support the work of Magdi Osman (2010) who reported that decreased carbohydrates level of fermented pearl millet flour at $24 \mathrm{hrs}$ was due to the increase in protein content.

The slight change in protein, fat, ash, fibre and carbohydrates content after 3 months of storage is non significant between the treatments; hence the changes did not influenced on quality and shelf-life of flour up to 3 months in all the samples (Table 1).

The changes in mineral and phytic acid contents of little millet flour as influenced by $S$. boulardii and $L$. acidophilus is presented in table 2 . The results on the minerals content of fermented little millet flour showed significant increase during fermentation with 
L. acidophilus with respect to Calcium (41.44 $\mathrm{mg} / 100 \mathrm{~g})$, Magnesium (141.08 mg/100g), Phosphorus $(234.43 \mathrm{mg} / 100 \mathrm{~g})$, Iron $(7.98 \mathrm{mg} / 100 \mathrm{~g})$ and Zinc (4.69 $\mathrm{mg} / 100 \mathrm{~g}$ ) compared to un inoculated control. This observation could be attributed to bio-synthesis and activities of microorganisms during fermentation processes (Gabriel and Akharaiyi, 2007). These results support the work of Antony and Chandra (1998) where such significant increase in mineral bioavailability when finger millet flour was fermented using endogenous grain micro flora. Sripriya, et al. (1997) reported significant increases in the mineral content of fermented finger millet due to the decrease in phytic acid content during fermentation.

Phytic acid content of little millet fermented by $S$. boulardii and $L$. acidophilus has significantly decreased phytic acid content. The highest reduction of phytic acid was observed in little millets fermented by L. acidophilus followed by combined inoculation of $S$. boulardii and L. acidophilus over an un inoculated control which had the highest phytic acid content (Table 2). The reduction of phytic acid is mainly due to the bioavailability of minerals during fermentation. Generally fermentation is known to cause greater reduction in phytic acid and this could be due to the low $\mathrm{pH}$ of fermented flours and may be attributed to microbial phytase. Similar findings were earlier reported by Magdi (2010) in pearl millet and Mardia, et al. (2001) in pearl millet fermentation. A significant reduction in phytic acid content was noticed during $24 \mathrm{hrs}$ of fermentation.

The results indicated that the population of $S$. boulardii and L. acidophilus was decreased from $10^{7}$ to $10^{6} \mathrm{cfu} /$ gm between inoculated treatments. The highest population of L. acidophilus $\left(3.21 \times 10^{6} \mathrm{cfu} / \mathrm{gm}\right)$ was recorded in little millet flour sample fermented by lactic acid bacteria followed by $S$. boulardii $\left(2.46 \times 10^{6} \mathrm{cfu} / \mathrm{gm}\right)$ (Table 3$)$. The significant reduction in $S$. boulardii and L. acidophilus population in the fermented flour samples could be due to acid production and reduction in $\mathrm{pH}$ by the influence of microbial fermentation. However, there is reduction in L. acidophilus population compared to $S$. boulardii population indicating that $S$. boulardii fermentation produced more acidity and more reduction in $\mathrm{pH}$, there by more reduction in $S$. boulardii population. Similar results were reported by Sorbhi et al. (2012) in mixed cereal substrates fermented by lactic acid bacterial cultures.

Similarly, during storage of flour, the $S$. boulardii and L. acidophilus population has significantly decreased at 45 and 90 days of storage period. The decrease of $L$. acidophilus population was $1.69 \times 10^{6}$ and $0.85 \times 10^{6}$ from $3.21 \times 10^{6} \mathrm{cfu} / \mathrm{g}$ at 45 and 90 days of storage respectively (Table 3 ). The decrease in population during storage may be due to the slight variation in proximate composition and slight temperature variation during storage period. Similarly, the decrease of $S$. boulardii population was $1.54 \times 10^{6}$ and $0.41 \times 10^{6}$ from $2.46 \times 10^{6} \mathrm{cfu} / \mathrm{g}$ at 45 and 90 days of storage respectively indicated that yeast population was more reduced compared to bacterial population during storage.

\section{Conclusion}

Fermentation of little millet (Panicum sumatrense) by combined inoculation of probiotic yeast ( $S$. boulardii) and LAB (L. acidophilus) was more effective in enhancement of protein. Fermentation of little millets by $L$. acidophilus was more effective in reducing phytic acid and increases the bioavailability of minerals.

\section{REFERENCES}

Amagloh, F.K., Weber, J.L. Brough, L. Hardacre, A., Mutukumiraa, N. and Coad, J. (2012). Complementary food blends and malnutrition among infants in Ghana: A review and a proposed solution Sci. Res. Essays.,7(9):972-988.

Antony, U. and Chandra, T.S. (1998). Antinutrient reduction and enhancement in protein, starch and mineral availability in fermented flour of finger millet (Eleusine coracana). J. Agric. Food. Chem., 46(7):2578-2582.

AOAC (1980). Official Methods of Analysis, 13th Edition. Association of Official Analytical Chemists, Washington, DC.

Chandru, R., Ranganna, B., Subramanyam, S. and Munishamanna, K.B. (2007) Quality evaluation of ragi flour packaged and marketed as ready to cook product in Karnataka RPF-III submitted to PC cell, PHT, ICAR, CIPHET, Ludhiana.

Chandru, R., Ranganna, B., Subramanyam, S., Palinimuthu, V. and Munishamanna, K. B. (2010). Studies on Extension of shelf life of finger millet flour. Mysore J. Agril. Sci., 44(1): 44-48.

Fasasi, O.S. (2009). Proximate antinutritional factors and functional properties of processed pearl millet (Pennisetumglaucum). J. Food Technol., 7(3): 92-97.

Gabriel, R.A.O. and Akharaiyi, F.C. (2007). Effect of spontaneous fermentation on the chemical composition of thermally treated jack beans (CanavaliaennsiformisL.). Int. J. Biol. Chem. 1(2): 91-97.

Haug, w. and Lantzsch, H.J. (1983).Sensitive method for the rapid determination of phytate in cereals and cereal products.J. Food Sci. Agric., 34: 1423- 1426.

Hoben, H.J. and Somasegaran, P. (1982).Comprison of the pour, spread and drop plate methods for enumeration of Rhizobium spp. In inoculants made from pre-sterilized peat. Appl. Environ.Microbiol., 14: 1246-1247.

Ijarotimi, O.S. (2012). Influence of germination and fermentation on chemical composition, protein quality and physical properties of wheat flour (Triticum aestivum). J. Cereals and Oil seeds India, 3(3): 35-47.

Inyang, C.U. and Zakari, U.M. (2008).Effect of germination and fermentation of pearl millet on proximate chemical and sensory properties of instant "fura"- A Nigerian cereal food. Pak. J. of Nutr., 7(1): 9-12.

Magdi, A.O. (2010).Effect of traditional fermentation process on the nutrient and antinutrient contents of pearl millet during preparation of Lohoh. J. Saudi Soc. Agric. Sci., 10: 1-6.

Mardia, E.E. Abdullahi, H.E. and Nabila, E.Y. (2001). Effect of fermentation and dehulling on starch, total polyphenols, phytic acid content and in vitro protein digestibility of pearl millet. Food chem., 77: 193-196. 
Obizoba, I.C. (1988).Nutritive value of malted, dry or wet milled sorghum and corn.Cereal chem., 65: 447-449.

Oyenuga, V.A. (1968). Nigeria foods and feeding stuffs: their chemistry and nutritive value. Ibadan: University Press.

Ranganna, B., Ramya, K.G., Kalpana, B. and Arunkumar, P. (2012). Nutri products from popped kodo and proso millet grains. Mysore J. Agric. Sci., 46(3): 500-504.

Reihaneh, A.G. and Jamuna, P. (2007). The impact of germination and dehulling on nutrients, antinutrients, in vitro iron and calcium bioavailability and in vitro starch and protein digestibility of some legume seeds. LWT., 40: 1292-1299.

Sharma, P. (2008).Minor millets of tribal area, Agrotech
Publishing Academy, Udaipur, India.

Sorbhi, R., Ivan, S. and Severino, S.P. (2012). Production of potentially probiotic beverages using single and mixed cereal substrates fermented with lactic acid bacteria culture. Food Microbiol., 30: 239-244.

Sripriya, G., Usha, A. and Chandra, T.S. (1997). Change in carbohydrates, free amino acids, organic acids, phytate and HCL extractability of minerals during germination and fermentation of finger millet (Eleusine coracana). Food Chem., 58(4): 345-350.

Wakil, S.M. and Kazeem, M.O. (2012). Quality assessment of weaning food produced from fermented cereal-legume blends using starters. Int. Food Res. J., 19(4): 1679-1685. 